
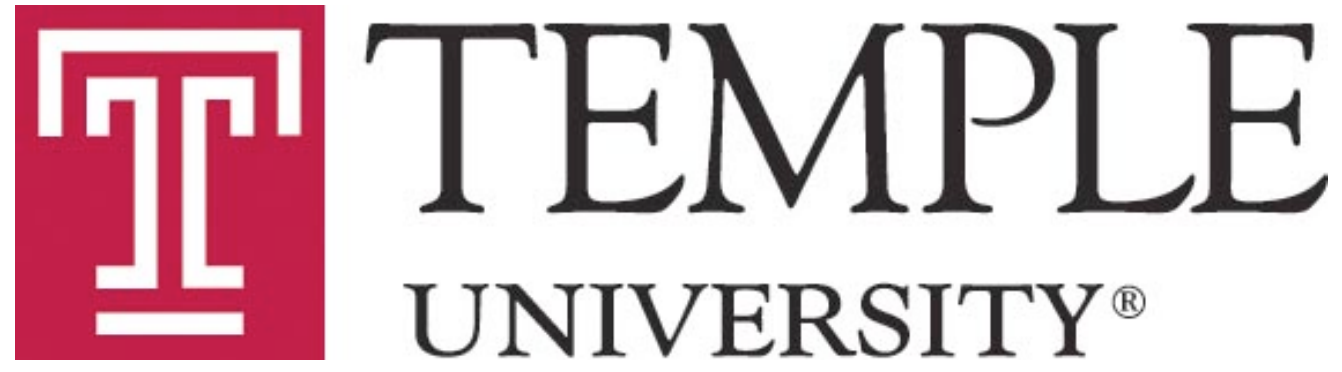

\title{
Do Entrepreneurial Goals Matter? Resource Allocation in New Owner-Managed Firms \\ by
}

William Dunkelberg

Carmen Moore

Jonathan Scott

William Stull

Department of Economics

DETU Working Paper 12-03

September 2012

1301 Cecil B. Moore Avenue, Philadelphia, PA 19122

http://www.cla.temple.edu/economics/index.htm 


\title{
Do Entrepreneurial Goals Matter? Resource Allocation in New Owner-Managed Firms*
}

\author{
William Dunkelberg ${ }^{2}$ \\ Carmen Moore ${ }^{3}$ \\ Jonathan Scott ${ }^{1}$ \\ William Stull ${ }^{4}$
}

Revised Draft

September 6, 2012

Key words: entrepreneurship, small business, new firms, owner goals, resource allocation

\begin{abstract}
* Earlier versions of this paper were presented at the following conferences: Academy of Entrepreneurial Finance, Chicago IL, September 2009; Eastern Economics Association, Philadelphia PA, February 2010; and International Atlantic Economic Society, Washington DC, October 2011. We would like to thank Andrew Buck, Peter Wirtz, Suzanne Clain, the journal editor, and three referees for helpful comments. Shu Deng provided valuable research assistance.
\end{abstract}

${ }^{1}$ Corresponding author. Department of Finance, 419 Alter Hall, 1801 Liacouras Walk, Temple University, Philadelphia, PA 19122-6083. jonathan.scott@temple.edu. Tel: (215) 204-7605; Fax: (215) 204-1697.

2 Department of Economics, Temple University. william.dunkelberg@temple.edu. Tel: (215) 204-6686; Fax: (215) 204-8173.

3 Department of Business Administration, Morgan State University. carmen.moore@morgan.edu. Tel: (215) 668-1862; Fax: (215) 204-8173.

4 Department of Economics, Temple University. stull@temple.edu. Tel: (215) 204-5022; Fax: (215) 204-8173.Abstract 
This paper focuses on how entrepreneurial goals affect the resource allocation of new firm owners. It connects research in psychology and management that examines the core motivations of entrepreneurs with research in economics that models the behavior of ownermanagers as utility-maximizing rather than profit-maximizing. We hypothesize that new owners with nonmonetary goals allocate their resources differently than do owners with monetary goals and that the differences are meaningful in size. To test these hypotheses, we estimate firm level equations based on economic theories of factor demand that show how input quantities depend on owner goals. Data come from a national survey of new U.S. business owners. We find owner goals have both a statistically and substantively significant effect on resource allocation for new firms. Owners with nonmonetary goals put in more of their own and family hours rather than hiring outside employees. Implications for research and policy are discussed. 


\section{Executive Summary}

The entrepreneurship literature has long recognized that entrepreneurs have different goals when starting a business, many of which are nonmonetary such as the desire to be one's own boss. The literature has been less definitive with regard to the behavioral significance of these goals. The research reported here focuses on the influence entrepreneurial goals have on new firm resource allocation. Once businesses are launched, entrepreneurs must decide on the appropriate input mix -- for example, how much labor should be provided by themselves or family members and how much by hired employees. If goals are behaviorally important, they should affect the outcomes of these decisions. While it would seem likely that entrepreneurs with nonmonetary goals operate their firms differently than do those with monetary goals, scant evidence exists to support this assertion.

Drawing on previous work in management, psychology, and economics, we construct a conceptual framework in which the input decisions of utility-maximizing entrepreneurs are partly determined by their goals. We then specify an econometric model based on this framework consisting of equations showing firm inputs as functions of the entrepreneur's goals and a set of standard economic control variables (industry, region, and human capital measures). The model is estimated using a unique dataset obtained from survey responses given by almost 3000 new business owners across regions and industries in the U.S. The most important attribute of the survey is that new owners choose among five primary goals for starting businesses that include both monetary and nonmonetary options and that align closely with core motivations found in other empirical studies. In addition, the survey includes measures of the most important new business inputs: owner hours worked per week, family hours worked per week, number of employees, and initial capital investment. 
We test two hypotheses:

1) entrepreneur goals affect new firm input allocation;

2) goal effects on inputs are quantitatively meaningful.

Our results show that entrepreneurs with nonmonetary goals make significantly different decisions regarding input allocations than do entrepreneurs with monetary goals in the early months of firm operation. Owners whose primary goal is nonmonetary use relatively more of their own and family labor and relatively less employee labor compared to owners whose primary goal is monetary. In addition, differences in input usage between monetary-goal and nonmonetary-goal entrepreneurs are reasonable in magnitude, particularly with regard to owner and family hours worked. For example, owners that launched their firms to "build a successful organization" worked on average about two weeks more per year than otherwise comparable owners whose primary goal was to "make more money."

In summary, the principal contribution of the paper is to demonstrate an empirically important link between entrepreneur goals and how new firms employ inputs. Because new firm outcomes are ultimately determined by entrepreneurial resource allocation decisions, our results have implications for both researchers and policy-makers. For the entrepreneurship research community, the findings suggest greater use of goal variables in theoretical and empirical models. Among other things, their inclusion will provide an alternative explanation for frequently-observed "non-entrepreneurial" behavior such as owners who refuse to close their businesses despite poor financial performance or owners who do not seek out opportunities for expansion. For policy-makers, they suggest paying more attention to entrepreneurs' nonmonetary goals in the evaluation of alternative small business tax policies, in the design of entrepreneur promotion programs, and in the assessment of entrepreneurial "success." 


\section{Introduction}

Firms do not start themselves. Someone -- the entrepreneur -- must make a conscious decision to commit the substantial time and resources needed to plan for and launch a new venture. ${ }^{1} \quad$ Because of the difficulty of accomplishing this task -- the risks that must be borne and the "impertinent obstructions" (Smith, 1776) that must be overcome -- individuals who undertake it must have strong motivations for doing so. Furthermore, given human diversity, such motivations are likely to differ from one entrepreneur to another.

The economists who created the first systematic theories of entrepreneurship recognized that people become entrepreneurs for a variety of reasons, only one of which is making money. Joseph Schumpeter (1912), for example, notes that individuals may launch new ventures out of the "joy of creating" or to establish a "private kingdom." Frank Knight (1921) observes that the "prestige of entrepreneurship" and "satisfaction of being one's own boss" must be taken into account in explaining entrepreneurial decision-making. Tibor Scitovsky (1943) develops a model in which the effect of rising income on an owner-manager's work effort depends on whether his primary goal is achieving "success" or a balanced life.

Considerable modern research on entrepreneurship builds on these fundamental insights. In the psychology and management literature, much theoretical and empirical work is based on the idea that there are a small number of core motivations for new venture creation that lie behind the much larger number of articulated reasons given by entrepreneurs. The terms used to describe these core concepts include "goals," "reasons," "purposes," "needs," "intentions," and "motivations." We use the term "goals" most frequently because it is the one used in the survey

\footnotetext{
${ }^{1}$ For discussions of the relative value of the "firm" versus "entrepreneur" perspectives, see Gartner (1989) and Sarasvathy (2004). Shane and Venkataraman (2000) propose a unifying conceptual framework.
} 
question asking our sample entrepreneurs to identify their primary reason for starting a business. The empirical studies in these fields find that core motivations almost always include both monetary and nonmonetary goals, but they do not conclusively demonstrate that entrepreneurs with different goals behave differently. In the economics literature, entrepreneurs are modeled as utility- rather than profit-maximizers, but little theoretical or empirical attention is paid to the possibility that goal differences might affect utility functions and thus entrepreneur decisionmaking.

Looking at both bodies of work together, it is clear that the relevance (or irrelevance) of goals to entrepreneur behavior has not been established. The primary purpose of the present study is to help close this gap in the literature. Specifically, we hypothesize that entrepreneurs with different goals will operate their businesses differently, other things equal -- or equivalently, that they will allocate their resources (e.g., labor and capital) differently. To investigate this relationship, we construct a conceptual framework based on economic theory that describes new venture resource allocation when entrepreneurs have different goals and then use this to specify an econometric model for testing hypotheses about the goal-input linkage. For the empirical work, we use a National Federation of Independent Business (NFIB) dataset containing survey information on almost 3000 new firms from all U.S. regions and major industry groups, including information on founder goals. The paper thus represents bridge research in entrepreneurship linking traditional concerns in psychology and management with those in economics. In this regard it is a continuation of recent work aimed at bringing the mainstreams of economics and entrepreneurial studies closer together (Douglas and Shepherd, 1999; Levesque et al., 2002; Parker, 2004; Minniti and Levesque, 2008; DeTienne et al., 2008; Campbell, 2009). 
The principal contribution of the paper is to demonstrate that the goals motivating individuals to become entrepreneurs have an important effect on how they run their new businesses. More specifically, our results show that goals exert both a statistically and substantively significant influence on the quantities of the inputs used by new firms across regions and industries in the U.S. economy. To the best of our knowledge, there is no published research that presents comparable findings.

The paper is organized as follows. Section 3 summarizes the relevant literature; Section 4 develops a conceptual framework for the empirical analysis and presents two hypotheses; Section 5 describes the data; Section 6 specifies the econometric model and discusses estimation methodology; Section 7 presents the empirical results; Section 8 summarizes the key findings, discusses their implications for research and policy, and suggests future avenues for research.

\section{Previous Research}

Comprehensive surveys of the entrepreneurial goals literature have been provided by other scholars (Carter et al., 2003; Santarelli and Vivarelli, 2006). We give an overview to indicate the literature's breadth and importance, and then use it to position our work relative to that of other researchers.

\subsection{Core Motivations}

Entrepreneurs as a group typically give many reasons for why they intend to start, or actually do start, new businesses. As a result, much attention has been paid in the goals literature to identifying simpler underlying motivational structures that can then "explain" (and thus be a substitute for) the wide variety of articulated reasons (Scheinberg and MacMillan, 1988; Birley and Westhead, 1994; Morton and Podolny, 2002). Empirical studies often begin by distilling 
core motivations from a larger group of reasons obtained from questionnaires, typically using factor analysis. Researchers do not always find the same core motivations, but some particularly those relating to achieving independence and making money - occur repeatedly.

Typically, core motivations do not represent the end product of a research project. Instead, they are "intermediate inputs" used to accomplish some larger intellectual purpose. Broadly speaking, three such purposes are commonly found in the literature: creating entrepreneur typologies (Dunkelberg and Cooper, 1982; Woo et al., 1991; Stewart et al., 2003), comparing goal distributions across different populations (Scheinberg and MacMillan, 1988; Carter, 1997; Kepler and Shane, 2007; Moore, 2007), and explaining entrepreneurial behavior and outcomes. Our paper belongs to the third of these research strands.

\subsection{Explaining Entrepreneurial Behavior and Outcomes}

Studies in this strand focus on the development and testing of theories linking the reasons individuals start businesses to actual (or anticipated) actions and outcomes - including becoming an entrepreneur in the first place. ${ }^{2}$ Goals thus function as independent variables in this body of work. Research in the first two strands listed above has been concentrated in the psychology and management literature. In this third strand there is research in both these fields and in economics, though the lines of inquiry have evolved independently.

\subsubsection{Psychology and Management Literature}

A variety of papers in this literature present theories which include goals as determinants of entrepreneurial behavior - the latter encompassing not only the decision to launch a business

\footnotetext{
2 In some cases the focus is on "intentions" in addition to, or instead of, behavior (Birley and Westhead, 1994; Douglas and Shepherd, 1999). As noted by Krueger et al. (2000), research in psychology has demonstrated that intentions are strong predictors of planned behavior "particularly when that behavior is rare, hard to observe, or involves unpredictable time lags."
} 
but also post-launch owner-manager actions and the outcomes that flow from them. ${ }^{3}$ Douglas and Shepherd (1999) and Levesque et al. (2002), for example, build formal utility-maximizing models of career choice in which the decision to be an entrepreneur depends on financial considerations and the desire for independence. In a study that goes beyond the launch process, Naffziger et al. (1994) construct a dynamic theory in which personal goals - both financial and nonfinancial - repeatedly affect what they refer to as the "decision to behave entrepreneurially." Other papers providing conceptual links between goals and entrepreneurial behavior include Kaufmann (1999), Krueger et al. (2000), and Shaver et al. (2001).

A considerable body of empirical research tests hypotheses emerging from these theories but with mixed results. Some papers report significant relationships between entrepreneurial goals and behavior while others do not. In the former group, Gatewood et al. (1995) find that female nascent entrepreneurs -- i.e., those in the process of creating a new firm -- are most likely to establish a business if their goals (e.g., the desire to be one's own boss) are internal and stable. Choo and Wong, in a more recent study (2006), find that nonfinancial goals are more important than financial goals in explaining the decision of retired Singapore military officers to launch a business. Other studies with results showing some causal connection between goals and behavior include Cooper and Dunkelberg (1986), Kolvereid (1996), and Buttner and Moore (1997)

Not all research efforts find this link, however. Birley and Westhead (1994), in a study of new British owner-managers, find significant differences among their respondents with regard to the reasons given for starting a business. However, these differences in reasons do not explain differences in firm success as measured by business size or growth. They conclude that their work supports the view that the reasons for starting a business have "minimal influence" on its

\footnotetext{
${ }^{3}$ A parallel approach for corporate leaders can be found in the upper echelons theory literature (Hambrick, 2007).
} 
future growth, wealth creation, and job generation. Carter et al. (2003) reach a similar conclusion with regard to the effect of goals on the decision to become an entrepreneur. Using data from the Panel Study of Entrepreneurial Dynamics (PSED I and PSED II; Reynolds and Curtin, 2008), they find only small differences between the goal distributions of nascent entrepreneurs and non-entrepreneurs. They conclude that researchers analyzing the decision to enter the startup phase of a new venture should focus on other behavioral and cognitive variables.

The current study builds on these prior studies in two ways. First, it accepts their fundamental premises concerning the core goals that motivate people to start businesses namely, that they are few in number and that they include both monetary and nonmonetary elements. Second, it recognizes that theoretical support for the proposition that goals affect entrepreneurial decision-making is relatively strong but that empirical support is mixed, with some researchers coming to negative conclusions concerning the overall value of goals as predictors of behavior. Our research is an extension of the empirical portion of this work and provides a new analysis of the goal-behavior linkage. The focus is on how goals affect a particular - and previously unstudied - dimension of entrepreneurial activity: the allocation of inputs in the early years of operation.

\subsubsection{Economics Literature}

A substantial body of theoretical research uses the standard tools of microeconomics to analyze the behavior of the owner-managed firm, nearly all of which derives from Scitovsky's 1943 article (Olsen, 1977; Hannan, 1982; Formby and Millner, 1985). The main objective of most of this work (though not of the research presented here) is to identify the theoretical utility function and market conditions under which utility-maximizing behavior by an owner-manager 
yields the same short- and long-run outcomes as (economic) profit-maximizing behavior. As a result, the papers are not specifically about new owner-managers, and few explicit connections are made to the reasons for starting a business that are the central concern of the present work. Goal differences can be an explanation for the utility function differences analyzed in the papers, but this possibility is only mentioned by a subset of the authors and usually only in a context that is outside the formal modeling process.

The empirical economics literature specifically addressing the link between goals and behavior is sparse. ${ }^{4}$ The two papers that come closest to the research presented here are by Morton and Podolny (2002) and Singell and Thornton (1997). The first focuses on the motivations for owning a California winery. The authors construct a model of winery owner behavior that partitions owners into two groups based on their goals: those in business for "love" and those in business for "money." They find that owner scores on the study's "love" and "money" variables have a statistically significant effect on pricing and quality decisions.

Singell and Thornton begin by noting that firm owners may have preferences regarding the types of labor they hire that are independent of relative productivity. They then build a model of firm input choice in which the labor input quantities appear in both the ownermanager's utility and production functions. This model is not based on the owner-manager's reasons for starting the business, but it does generate input demand relationships that depend on his "tastes" (as embodied in his utility function) for certain inputs separate from their contribution to profit. Analysis of the model leads to the prediction that owner-managers with different tastes will hire inputs in different proportions. The empirical portion of the study, using a small sample of family-operated Utah dairy farms divided into "utility-maximizers" and

\footnotetext{
${ }^{4}$ Some indirect evidence for the significance of nonmonetary goals in the decision to be one's own boss can be found in the self-employment literature (Hamilton, 2000; Moskowitz and Vissing-Jorgensen, 2002; Åsteboro and Thompson, 2007).
} 
"profit-maximizers," finds that utility-maximizing farms use more family-owned labor and capital relative to hired labor than do profit-maximizing farms.

Both the conceptual framework for the present paper and the econometric model based on this framework derive from these earlier lines of inquiry. As will be discussed in more detail in the next section, our conceptual framework is essentially the same as the one underlying the theoretical papers analyzing the behavior of the owner-manager. Our econometric model is different from the ones used by Morton and Podolny (2002) and Singell and Thornton (1997) but with significant overlap. We estimate firm level input relationships, as does Singell and Thornton (but not Morton and Podolny), and we use reasons for starting businesses as independent variables, as does Morton and Podolny (but not Singell and Thornton). It differs from the models used in both papers in its explicit use of goals identified as important in earlier studies, in its exclusive focus on new firms, and in its application to firms in a wide variety of industries and regions.

\section{Conceptual Framework and Hypotheses}

The conceptual framework for our research is derived from established economic theories of input decision-making by the competitive firm. Traditional textbook microeconomic theory (e.g., Henderson and Quandt, 1980) assumes the firm maximizes profit (the difference between total revenue and cost) with respect to input quantities subject to its production function and exogenous prices. These assumptions lead to a set of firm level input demand equations, one for each input, in which the dependent variables are input quantities and the independent variables are input prices and output prices. In the general case, all prices enter into each demand relationship. 
The theoretical literature on the owner-managed firm cited in the previous section modifies the textbook input demand model in three ways. First, it separates owner-provided inputs (mainly labor) from those purchased in the market. The latter are included in the firm's (accounting) cost relationships, the former are not. Second, it assumes that the results of firm decision-making - specifically, the allocated quantities of owner-provided and (in some papers) purchased inputs and the resulting accounting profit - are evaluated subjectively by the ownermanager. This means that owner-managers are modeled as utility- rather than profit-maximizers with utility functions whose arguments include both accounting profit and variables representing sources of non-market costs and benefits that may result from firm ownership and control - most commonly input quantities (or their opposite in the case of labor inputs, leisure). ${ }^{5}$ Third, it assumes that different owners can have different "tastes" with regard to the relative importance of the elements in their utility functions. In Scitovsky's classic paper (1943), for example, all owner-managers value leisure and accounting profit (both entering their utility functions) and face a trade-off between them, but they differ in the relative value they assign to these "goods" as indicated by the slopes of their indifference curves at different income levels. Utility maximization in the owner-managed firm model yields input demand equations that depend on the owner-manager's utility function as well as his production function and market prices.

Our conceptual framework takes the owner-managed firm model as its point of departure and adds three additional assumptions. The first is that the business is a new one so we can

\footnotetext{
5 All models in this literature assume the marginal utility of leisure is always positive, implying the marginal utility of work effort is always negative. This assumption yields conventional downward-sloping indifference curves for the owner in accounting profit-leisure space. Many entrepreneurs are "workaholics," however, who seem to prefer work to leisure. This suggests an alternative specification for the entrepreneur utility function wherein the marginal utility of work is positive (and hence the marginal utility of leisure is negative) for initial work hours but then turns negative as hours increase beyond some point. This approach yields $U$-shaped indifference curves. As long as accounting profit increases with work effort, however, the utility-maximizing quantity of work hours will always be in the range where the marginal utility of work is negative. For arguments for and against "effort-preferring" entrepreneurs, see Douglas and Shepherd (1999).
} 
legitimately refer to the owner-manager as an entrepreneur. The second is that the entrepreneur's utility function is determined by his primary goal in launching his business. The third is that the arguments in his utility function include not only his own labor hours (as in the Scitovsky model) but also the quantities of the other inputs. In this setting, utility maximization leads to firm input quantities that depend explicitly on the entrepreneur's primary goal.

More specifically we assume (following Singell and Thornton, 1997) that our firms use four primary inputs to produce output: owner labor, family labor, employee labor, and capital. These are the entrepreneurs' decision variables. Neither owners nor family members are paid a wage for their labor input. Instead, families are compensated as a whole out of accounting profit. Input prices for employee labor and capital and output price are exogenous. The firms' production functions vary by industry and have the quantities of the four inputs as arguments. Our database provides measures of entrepreneur education and experience. These human capital indicators are also included as arguments in the production function to take account of their likely effect on the marginal productivity of the primary inputs. ${ }^{6}$

Building on the earlier goals research (Morton and Podolny, 2002; Choo and Wong, 2006), we assume that entrepreneurs have different reasons for starting businesses, that these reasons are small in number and exogenous, and that they include both monetary and nonmonetary objectives. ${ }^{7}$ To integrate this approach with the owner-manager literature, we assume all entrepreneurs have a single primary goal which can be either monetary or nonmonetary (e.g., building an organization). Each entrepreneur then has a utility function

\footnotetext{
${ }^{6}$ A more formal description of the production and utility functions that underlie our conceptual framework may be found in the Appendix.

${ }^{7}$ The exogeneity assumption means that the paper does not seek to explain goal differences among entrepreneurs or goal changes over time by any given entrepreneur. The first of these topics is addressed in the literature on goal distributions across populations cited in Section 3.1. The second is the central concern of the literature on retrospection bias cited in Section 5.3.
} 
whose parameters depend on his primary goal and whose arguments are accounting profit and the quantities of the four inputs. The inclusion of labor and capital quantities in the utility function allows an entrepreneur to receive direct utility (or disutility) from these inputs beyond their contribution to accounting profit (Errington and Gasson, 1994; Singell and Thornton, 1997).

Given utility functions with these features, new owners with different goals may choose different input combinations. Consider, for example, an entrepreneur whose primary (nonmonetary) goal is building an organization. Utility maximization by this individual may lead him to allocate more of his own and family labor to the enterprise (in an effort to create a larger firm) than would be allocated by an otherwise identical entrepreneur whose primary goal was monetary.

Overall, this framework specifies that new firm input quantities depend on both entrepreneur goals and standard economic variables -- input prices, output prices, and production function characteristics. The main purpose of the present research is to assess the strength of the goal variable effects on input allocations controlling for all other influences. To do this, we test two hypotheses. The first focuses on the statistical significance of these effects:

Hypothesis 1: Entrepreneur goals affect new firm input allocation.

Entrepreneur goals may have a statistically significant effect on inputs, but such a finding is not particularly important unless the effect is economically meaningful. For example, if new owners with nonmonetary goals worked 0.5 hours per week more than those with monetary goals, the result, even if statistically significant, would not be substantively significant if owners overall averaged 60 hours per week. The second hypothesis thus focuses on effect sizes:

Hypothesis 2: Goal effects on inputs are quantitatively meaningful. 


\section{Data}

\subsection{Sample Description}

The research reported here uses a dataset obtained from the first year of a three-year panel study of new business owners conducted by the NFIB from 1985 to 1987 (Cooper et al., 1990). In May 1985, the NFIB sent initial questionnaires to the approximately 13,000 organization members who reported that they had recently become business owners. Of the 4,814 that were returned, only the 2,994 firms reporting a first sale in 1984 or the first five months of 1985 were selected for further analysis. The purpose of the first sale requirement was to exclude nascent firms from the sample (distinguishing it from the PSED samples which only include such firms). ${ }^{8}$ In addition to having made a first sale, $75 \%$ of the 2,994 firms had the equivalent of two or more full-time employees at the time of the survey.

Data were collected on a wide variety of entrepreneur and firm characteristics. Table 1 gives an overview. Respondents were predominantly male, not members of a minority group, and between the ages of 25 and 54. Most also did not have a baccalaureate degree and had never previously owned a business. More than $75 \%$ had prior supervisory or management experience, however; and almost 50\% had parents who owned a firm. Their businesses were distributed across the eight U.S. Census regions and nine industries, with a heavy concentration in the retail and service sectors. Almost $70 \%$ of the firms were newly created and over $70 \%$ had only a single owner. Nearly $90 \%$ made their first sale within three months after their first major business expenditure.

\subsection{Variables}

8 We assume the nascency period ends with the first sale. The PSED ending point is slightly different (Reynolds, 2000). 
The dependent variables in our empirical model are firm input quantities and the key independent variables are the primary goals of the new owners. As noted in the previous section, inputs may also depend on more objective factors such as prices, production function characteristics, firm ownership structure, and firm mode of acquisition. We capture the influence of these using a set of control variables that differ in general from the specific economic variables identified by the textbook and owner-manager models. We therefore do not interpret our estimated relationships as input demand functions.

\subsubsection{Dependent Variable: Inputs}

The NFIB survey provides measures for the four primary resource inputs identified in the conceptual framework: owner labor $\left(\mathrm{L}_{\mathrm{O}}\right)$, family labor $\left(\mathrm{L}_{\mathrm{F}}\right)$, employee labor $\left(\mathrm{L}_{\mathrm{E}}\right)$ and capital $(\mathrm{K})$. Table 2 displays the relevant summary statistics. $\mathrm{L}_{\mathrm{O}}$ is owner hours per week; it has a mean value of 56.5 hours and a median value of 60.0 hours, with almost $80 \%$ of the respondents reporting between 41.0 and 80.0 hours. $\mathrm{L}_{\mathrm{F}}$ is unpaid family hours per week with a mean of 15.9 hours and a median of zero hours. $\mathrm{L}_{\mathrm{E}}$ is the number of employees measured in full-time equivalents (FTEs) with part-time workers counted as $0.5 \mathrm{FTE}$. The mean and median values for this measure are 4.7 and 3.0 respectively. K, initial capital investment, was collected using the intervals shown in Table 2 rather than in specific dollar amounts. Using the midpoints of all the categories except the last where $\$ 500,000$ is used, the mean value for this measure is slightly more than $\$ 51,000$ and the median value is $\$ 34,000$.

The first three $\left(\mathrm{L}_{\mathrm{O}}, \mathrm{L}_{\mathrm{F}}, \mathrm{L}_{\mathrm{E}}\right)$ are count measures - i.e., variables that only take on nonnegative integer values. ${ }^{9}$ The distributions of two of these, $\mathrm{L}_{\mathrm{F}}$ and $\mathrm{L}_{\mathrm{E}}$, are highly skewed. The

\footnotetext{
${ }^{9}$ Employees are reported in FTEs resulting in many values ending in 0.5 . Because of this, the series had to be rescaled (multiplied by 2 ) to convert all values into integers.
} 
fourth dependent variable, $\mathrm{K}$, is categorical and ordered. These distributional characteristics affect the choice of estimation procedure.

\subsubsection{Independent Variables: Goals}

The question in the NFIB survey that we use to identify an entrepreneur's primary goal is: "When you went into your business, what were your most important goals?" The choices are:

* Make more money than you would have otherwise (MO)

* Let you do the kind of work you wanted to do (WK)

* Avoid having to work for others (AV)

* Build a successful organization (BU)

* Other/No response (OT).

Owners rated the choices from most important to least important on a five-point scale. The distribution of first choice (i.e., primary) goals is shown in Table 3. The most frequent first choice is $\mathrm{BU}$, chosen by $29 \%$ of the respondents, followed by WK chosen by $25 \%$. MO and $\mathrm{AV}$ were chosen by $17 \%$ and $18 \%$ of the respondents respectively. Only $10 \%$ chose the other category or gave no response (OT). The NFIB goals, in addition to being intuitively reasonable, align closely with core motivations for starting businesses found in many other studies (Scheinberg and MacMillan, 1988 Shane et al., 1991; Kuratko et al., 1997; Carter et al., 2003; Choo and Wong, 2006; Reynolds and Curtin, 2008). Goals enter the empirical model as dummy variables. There are four such variables (for five goals), each taking on the value one for a particular primary goal and zero otherwise.

\subsubsection{Independent Variables: Controls}

There are three groups of control variables. Summary statistics are presented in Table 4. The first group consists of variables that capture the industry and price effects identified in the 
conceptual framework. Firms in different industries have different production functions and face different input and output prices. In addition, input and output prices for firms in the same industry may vary by region. Following the procedure used by many other empirical studies of firm and entrepreneur behavior (Graves and Langowitz, 1996; Westhead et al., 2001; Townsend et al., 2010; Ucbasaran et al., 2010; Chua et al., 2011), we control for such influences using dummy variables: eight industry variables (for nine industries, using 2-digit SIC classifications) and seven regional variables (for eight regions). ${ }^{10}$ Because of the importance of labor in most small-scale production processes, we supplement these dummy variables with a separate measure of the price of labor: industry-region wage, the median industry wage rate by region in 1985 (computed using data from U.S. Department of Commerce, Bureau of Economic Analysis, Regional Economic Information System database). ${ }^{11}$

The second group of controls accounts for production function differences arising from differences in the human capital entrepreneurs bring to their new businesses. Inclusion of such variables is standard practice in empirical studies of entrepreneurship (Watson et al., 2003; Cassar and Craig, 2009; Townsend et al., 2010; Ucbasaran et al., 2010). Included in this group are measures of the owner's age, education level, number of business classes, number of previous full-time jobs, management experience, business ownership experience, and parents' business ownership experience. Each of these variables enters the empirical model in categorical form. There are three age dummy variables (for four categories); four education dummies (for five categories); three business class dummies (for four categories); five previous jobs dummies

\footnotetext{
10 For a discussion of the strengths and weaknesses of such imperfect proxies see Wooldridge (2002).

11 With regard to the price of capital, approximately $50 \%$ of the financing for the typical sample firm comes from personal savings or loans from "friends, family, and fools," the opportunity cost of which is unlikely to vary much by region or industry (Cooper et al., 1990; Dunkelberg and Scott, 2011). We assume price differences for the remaining 50\% are captured by the region and industry dummy variables (particularly the latter).
} 
(for six categories); and single dummy variables $(\mathrm{Yes}=1)$ for management experience, previous ownership, and parents' previous ownership.

Not all entrepreneurs are the sole owners of newly created businesses as assumed in the conceptual framework. As shown in Table 1, the NFIB sample includes new owners who purchased the firm (28\%), inherited the firm (2\%), or were brought in to take it over $(3 \%)$. It also includes owners with one partner $(20 \%)$ and with two or more $(9 \%)$. Firms deviating from the single-owner-of-new-firm prototype are likely to have different resource allocation patterns than otherwise identical non-deviating firms. For example, firms with multiple partners might have greater access to resources and therefore be larger (i.e., have more capital goods and employees) than single-owner firms. The third group of controls consists of two dummy variables included to capture such effects. The first, non-startup, captures "entrepreneurial mode" (i.e., how the new owner acquired the business); it takes on the value zero for the startup case and one for the non-startup case. The second, partners, captures the firm's ownership structure; it takes on the value zero for the no-partner case and one for the one-or-more-partners case.

\subsection{Data Assessment}

The NFIB survey data has four distinct strengths given the objectives of this paper. First, the sample is both large and comprehensive. Most empirical studies of entrepreneur behavior are based on datasets with a small number of cases and limited industry coverage. Studies using the PSED survey data are exceptions to this statement, but the PSED I and PSED II initial interview samples are still only $28 \%$ and $40 \%$ respectively of the NFIB sample size (Reynolds and Curtin, 2008). Second the NFIB dataset contains detailed information on both the new owner and his firm. It provides not only the study's dependent variables (resource inputs) and key independent 
variables (goals) but also many other firm and owner descriptors that enter the empirical model as controls. Third, the NFIB goal variables are well aligned with the core motivations for starting businesses found in other studies. Fourth the NFIB firms are new and in operation. This means that we test for goal effects in firms that are no longer nascent (unlike those in PSED) and do so at a moment in their history -- within 17 months of the first sale -- when these effects are likely to be the strongest. It also means that retrospection bias -- the difference between actual goals at the time of startup and goals reported later (Carter et al., 2003) -- is likely to be small. Because of these features, it is the only dataset of any vintage available for the purposes of this study.

A potential weakness of the NFIB dataset is its age. There is little doubt that the profile of new businesses (including, possibly, the nature and distribution of owner goals) has changed in the U.S. since 1985. However, such a change does not imply that the underlying relationship between goals and inputs -- the focus of this study -- has also changed. In our view, the goalinput linkage is a relationship ultimately rooted in human psychology and thus unlikely to vary much over time. ${ }^{12}$ We believe, therefore, that the results presented in Section 7 are applicable to current U.S. entrepreneurs. ${ }^{13}$

\section{Empirical Model and Estimation Methodology}

\footnotetext{
12 If the underlying relationship -- the so-called population regression equation (Greene, 2007) -- has not changed, estimation with 1985 data yields results that are statistically no worse (or better) than those that would be obtained with data from later years. If it has changed, the only way to get good estimates is to use current data which, as noted above, do not exist.

${ }^{13}$ Evidence in support of the continuing relevance of the NFIB survey more generally can be found in the citation statistics for earlier articles using this dataset. The Cooper et al. study of new firm performance (1994), for example, was cited over 500 times between 2000 and 2010.
} 
Our formal empirical model consists of the following four equations (assuming linearity and omitting case numbers and error terms):

$$
\begin{aligned}
& \mathrm{L}_{\mathrm{O}}=\alpha_{1}+{ }^{2} \beta_{1}\left({ }^{2} \mathrm{X}\right)+{ }^{3} \beta_{1}\left({ }^{3} \mathrm{X}\right)+{ }^{4} \beta_{1}\left({ }^{4} \mathrm{X}\right)+{ }^{5} \beta_{1}\left({ }^{5} \mathrm{X}\right)+\text { control terms } \\
& \mathrm{L}_{\mathrm{F}}=\alpha_{2}+{ }^{2} \beta_{2}\left({ }^{2} \mathrm{X}\right)+{ }^{3} \beta_{2}\left({ }^{3} \mathrm{X}\right)+{ }^{4} \beta_{2}\left({ }^{4} \mathrm{X}\right)+{ }^{5} \beta_{2}\left({ }^{5} \mathrm{X}\right)+\text { control terms } \\
& \mathrm{L}_{\mathrm{E}}=\alpha_{3}+{ }^{2} \beta_{3}\left({ }^{2} \mathrm{X}\right)+{ }^{3} \beta_{3}\left({ }^{3} \mathrm{X}\right)+{ }^{4} \beta_{3}\left({ }^{4} \mathrm{X}\right)+{ }^{5} \beta_{3}\left({ }^{5} \mathrm{X}\right)+\text { control terms } \\
& \mathrm{K}=\alpha_{4}+{ }^{2} \beta_{4}\left({ }^{2} \mathrm{X}\right)+{ }^{3} \beta_{4}\left({ }^{3} \mathrm{X}\right)+{ }^{4} \beta_{4}\left({ }^{4} \mathrm{X}\right)+{ }^{5} \beta_{4}\left({ }^{5} \mathrm{X}\right)+\text { control terms. }
\end{aligned}
$$

The dependent variables are the four input quantities described in Section 5.2.1. The ${ }^{\mathrm{j}} \mathrm{X}^{\prime} \mathrm{s}$, are dummy variables which capture the goal effects. We define and label them as follows:

$$
\begin{aligned}
& { }^{2} \mathrm{X}=1 \text { if the entrepreneur's primary goal is WK, } 0 \text { otherwise (dwork) } \\
& { }^{3} \mathrm{X}=1 \text { if the entrepreneur's primary goal is } \mathrm{AV}, 0 \text { otherwise (davoid) } \\
& { }^{4} \mathrm{X}=1 \text { if the entrepreneurs primary goal is BU, } 0 \text { otherwise (dbuild) } \\
& { }^{5} \mathrm{X}=1 \text { if the entrepreneur's primary goal is OT, } 0 \text { otherwise (dother) }
\end{aligned}
$$

Primary goal MO is the excluded category in this specification.

In the case of a new owner whose primary goal is monetary (MO), all the ${ }^{\mathrm{j}} \mathrm{X}^{\prime} \mathrm{s}$ in (1) are equal to zero and the constant terms in the four equations are $\alpha_{i}(i=1,2,3,4)$. In the case of an owner with nonmonetary goal $\mathrm{j}(=2,3,4$, or 5$)$, the four constant terms are $\alpha_{\mathrm{i}}+{ }^{\mathrm{j}} \beta_{\mathrm{i}}$. When ${ }^{\mathrm{j}} \beta_{\mathrm{i}}>$ 0 , the nonmonetary-goal owner uses more input $\mathrm{i}$ than does an otherwise identical monetary-goal owner, presumably because the additional units help him achieve his nonmonetary goal separate from their contribution (positive or negative) to accounting profit. When ${ }^{\mathrm{j}} \beta_{\mathrm{i}}<0$, the nonmonetary-goal owner uses less of the input than the monetary-goal owner; and when ${ }^{\mathrm{j}} \beta_{\mathrm{i}}=0$, the two types of owners use equal quantities. 
We found no theoretical justifications in the literature for making prior assumptions about the signs of the ${ }^{\mathrm{j}} \beta_{\mathrm{i}}$ 's, and it appears that plausible arguments can be made for either positive or negative effects. For example, we noted earlier that an entrepreneur with the nonmonetary goal of building an organization might allocate more own and family labor to the enterprise than a monetary-goal entrepreneur. It is also possible, however, that he will do the opposite -- choosing to substitute employee labor and capital for own and family labor because the former are more visible indicators of organization size. Because of such ambiguities, we choose not to impose a priori sign restrictions on the ${ }^{\mathrm{j}} \beta_{\mathrm{i}}$ 's.

With regard to our formal hypothesis testing procedure, we make two further decisions. The first is to perform hypothesis tests separately for each equation in (1) to allow for the possibility that goal differences could affect the use of some inputs and not others. The second is to deemphasize individual coefficient tests (though we report these) in favor of joint tests on all the ${ }^{\mathrm{j}} \beta_{\mathrm{i}}$ 's within an equation. We do this again because we do not have strong prior convictions concerning the signs of the individual coefficients. The structure for the joint tests of the null hypotheses against the alternatives is as follows:

$$
\begin{array}{lll}
\text { LO. } & \mathrm{H}_{0}:{ }^{2} \beta_{1}={ }^{3} \beta_{1}={ }^{4} \beta_{1}={ }^{5} \beta_{1}=0 & \mathrm{H}_{\mathrm{A}}: \text { At least one } \neq 0 . \\
\text { L } & \mathrm{H}_{0}:{ }^{2} \beta_{2}={ }^{3} \beta_{2}={ }^{4} \beta_{2}={ }^{5} \beta_{2}=0 & \mathrm{H}_{\mathrm{A}}: \text { At least one } \neq 0 . \\
\text { LE. } & \mathrm{H}_{0}:{ }^{2} \beta_{3}={ }^{3} \beta_{3}={ }^{4} \beta_{3}={ }^{5} \beta_{3}=0 & \mathrm{H}_{\mathrm{A}}: \text { At least one } \neq 0 . \\
\text { K. } & \mathrm{H}_{0}:{ }^{2} \beta_{4}={ }^{3} \beta_{4}={ }^{4} \beta_{4}={ }^{5} \beta_{4}=0 & \mathrm{H}_{\mathrm{A}}: \text { At least one } \neq 0 .
\end{array}
$$

In any equation where the null hypothesis is rejected, we can conclude that at least one type of nonmonetary-goal owner hired on average a different quantity of the input than did an otherwise identical monetary-goal owner. 
Two econometric issues arise given the structure of the formal model in (1) and the data used to estimate it. First, inasmuch as each owner decides jointly on input quantities, it is likely that there is contemporaneous correlation of the error terms within firms across the inputs. In general, ordinary least squares (OLS) estimators in such situations are unbiased and consistent but less efficient than a seemingly unrelated regression (SUR) estimator that takes these correlations into account. The regressors in (1), however, are the same in each of the input equations. In this special case, OLS estimators are the same as the SUR estimators (Greene, 2007). On the basis of this result we chose to estimate the equations in (1) independently. The second estimation issue is more important. As noted in the previous section, the dependent variables have distributional characteristics that make OLS a poor choice for estimating coefficients consistently. In particular, $\mathrm{L}_{\mathrm{O}}$ (owner hours), $\mathrm{L}_{\mathrm{F}}$ (unpaid family hours), and $\mathrm{L}_{\mathrm{E}}$ (employees) are counts, the latter two with skewed distributions; and $\mathrm{K}$ (initial capital investment) is a set of ordered categories. Poisson regression (PR) is the typical approach used to estimate relationships where the dependent variable is a count (Greene, 2007). However, this technique requires that the conditional mean and variance of the dependent variable be equal. If the variance is greater than the mean (the overdispersion case), negative binomial regression (NBR) is a more appropriate tool. To test for overdispersion we estimate the $\mathrm{L}_{\mathrm{O}}, \mathrm{L}_{\mathrm{F}}$, and $\mathrm{L}_{\mathrm{E}}$ equations using NBR and compute the associated values and confidence intervals for alpha, the estimated overdispersion parameter. In each case we reject the null hypothesis of no overdispersion indicating the use of NBR instead of PR. The K equation is estimated using ordered logit. Finally, the standard errors in all four equations are computed using robust procedures with clustering by industry. ${ }^{14}$

\footnotetext{
${ }^{14}$ Estimation with robust standard errors does not change the regression coefficients but produces estimates of the standard errors that are less sensitive to deviations from the standard assumptions of normality and
} 


\section{Results}

The principal findings of this study are given in Tables 5 and 6 . The former presents results that demonstrate the statistical significance of the goal-input linkage, supporting Hypothesis 1 . The latter presents results that demonstrate the substantively significance of the linkage, supporting Hypothesis 2. Table 7 reports the outcome of a robustness test. Throughout, the analysis focuses on the relationship between goals and input choice with limited discussion of results for the control variables.

\subsection{Hypothesis 1}

The first four rows in Table 5 report the estimated coefficients and standard errors for the four goal dummy variables in each input equation. The next 24 rows report comparable information for the control variables. Wald linear restriction tests are used to test the joint goal variable hypotheses in (2), the results of which are reported in the third and fourth rows from the bottom. Results for the overdispersion tests described above are presented in the last two rows.

The Wald test results provide strong support for Hypothesis 1. The null hypothesis that all goal coefficients equal 0 is rejected at the 0.00 level for the $\mathrm{L}_{\mathrm{O}}$ and $\mathrm{L}_{\mathrm{F}}$ equations, rejected at the 0.05 level for the $\mathrm{L}_{\mathrm{E}}$ equation, and nearly rejected at the 0.10 level for the $\mathrm{K}$ equation. For each of the inputs we thus conclude that there is at least one class of nonmonetary-goal entrepreneurs in the NFIB dataset whose allocations differ from those of monetary-goal entrepreneurs. Because of the differences in significance levels across equations, however, we are more confident about the presence of goal effects with regard to the labor inputs than with regard to the capital input.

homoscedasticity. The clustering option was chosen to control for the possibility that error variances are different for different industries. 
These conclusions are consistent with the results of the individual coefficient tests which show that half of the 16 coefficients across the four input equations are significant at least at the 0.10 level (using two-tailed tests). In addition, each goal variable is significant in at least one input equation, and each input equation has at least one significant goal variable. Finally, the results are weakest for the $\mathrm{K}$ equation where just one goal coefficient is significant and only at the 0.10 level.

In both the $\mathrm{L}_{\mathrm{O}}$ and $\mathrm{L}_{\mathrm{F}}$ equations all four goal coefficients are positive, and three in each equation are statistically different from zero (six of the eight such coefficients overall). This suggests that the biggest difference between monetary-goal and nonmonetary-goal entrepreneurs in the NFIB dataset is that the latter use more family-provided labor inputs, a result that is broadly consistent with the findings of Singell and Thornton's study of Utah dairy farmers (1997). In the $\mathrm{L}_{\mathrm{E}}$ equation, the effects are the opposite. Three of the four goal coefficients are negative (with one statistically significant). These results indicate that at least some of the increased use of owner and unpaid family labor by nonmonetary-goal entrepreneurs is at the expense of employee labor.

\subsection{Hypothesis 2}

Table 6 presents marginal effects computed from the goal coefficient estimates in the first four rows of Table 5. Because the statistical significance of the goal variables in the K equation is weak, Table 6 only presents results for the three labor equations.

Marginal effects are strongest statistically in the $\mathrm{L}_{\mathrm{O}}$ and $\mathrm{L}_{\mathrm{F}}$ relationships. The first of these shows that BU entrepreneurs worked about 2.6 hours more per week than monetary-goal entrepreneurs, or approximately 130 hours per year. This difference is equivalent to slightly more than two additional work weeks per year, given that the average entrepreneur in our sample 
worked 56.5 hours per week. WK entrepreneurs worked slightly fewer additional hours per week (2.0), and OT entrepreneurs slightly more (2.9). In the $\mathrm{L}_{\mathrm{F}}$ equation, the effects are greater. $\mathrm{AV}$ entrepreneurs used 8.0 more family hours per week than monetary-goal entrepreneurs, which translates into about ten additional 40 -hour work weeks per year. OT entrepreneurs used slightly more additional family hours (9.1) and BU entrepreneurs somewhat fewer (2.4). Only davoid has a statistically significant marginal effect in the $\mathrm{L}_{\mathrm{E}}$ equation. $\mathrm{AV}$ entrepreneurs hired about 0.54 fewer full-time employees than did monetary-goal entrepreneurs, a difference equivalent to approximately 25 additional 40-hour work weeks per year.

Overall, the magnitudes of these effects seem reasonable; they are neither trivial nor of overwhelming importance. We conclude that they provide strong support for Hypothesis 2.

\subsection{Robustness}

To assess the robustness of our results, we estimated the equations in (1) using several alternative specifications and estimation techniques. In each case, the results for the goal variable coefficients and hypothesis tests were not meaningfully different from those presented in Table 5. All, therefore, supported Hypotheses 1 and 2. In this section, we briefly examine the results of one such assessment.

The control variables in (1) include a dummy variable for entrepreneurial mode (nonstartup) and a dummy variable for ownership structure (partners); they are included to capture the direct effects that mode of acquisition or number of partners might have on input allocation. An additional possibility is that some interaction exists between these variables and the goal variables -- i.e., that the effect of any particular goal on the quantity of an input chosen might depend (say) on whether the firm was a startup or non-startup. A priori arguments can be made in support of the plausibility of such interactions. For example, in the non-startup case the input 
mix at the time of acquisition might limit (at least temporarily) the owner's ability to make an allocation that is more aligned with his primary goal.

An alternative specification that takes such effects into account adds eight interaction variables to each of the input equations shown in Table 5: four goal $\mathrm{x}$ non-startup dummies and four goal $\mathrm{x}$ partners dummies. The results of estimating the input equations including these terms are presented in Table 7. Focusing only on the goal coefficients, we see, first, that the joint Wald test results continue to provide strong support for Hypotheses 1. Second, while the individual goal coefficients in Table 7 differ somewhat from those in Table 5, the effect sizes computed from them (not reported here) are of the same sign and order of magnitude as those shown in Table 6, supporting Hypotheses 2. Based on this and other experiments, we believe that our conclusions regarding Hypotheses 1 and 2 drawn from Tables 5 and 6 are robust with regard to alternative specifications or estimation methods. ${ }^{15}$

\section{Discussion}

\subsection{Key Findings}

Research on the behavioral significance of entrepreneur goals in general and on the goalinput linkage in particular has been limited in scope with few well-established conclusions. The primary objective of this paper is to fill this gap in the literature by demonstrating that entrepreneurs with different reasons for starting their businesses allocate their labor and capital differently. We derive hypotheses from a conceptual framework based on the utility-maximizing behavior of entrepreneurs with alternative goals (monetary and nonmonetary) and test them using data from a large national survey of new business owners. Our results dictate rejection of

\footnotetext{
${ }^{15}$ Separate estimations were also run for only those owners that started a new firm and had no partners. The results for the goal variables were statistically and economically very similar to those in Table 5 .
} 
the null hypothesis that monetary-goal and nonmonetary-goal entrepreneurs deploy their resources in the same way during the first months of firm operation. In addition, more specific findings show that owners whose primary goal is nonmonetary use relatively more of their own and family labor and relatively less employee labor compared to owners whose primary goal is monetary. Finally, effect size computations indicate that the differences between monetary-goal and nonmonetary-goal entrepreneurs are substantively meaningful and reasonable in magnitude. These results have implications both for entrepreneurship researchers and for policy-makers seeking to promote entrepreneurship in the economy.

\subsection{Implications for Research and Policy}

\subsubsection{Research}

New firm future outcomes (survival, profitability, growth) are ultimately the result of entrepreneurial resource allocation decisions. Given the importance of outcomes, our finding that ex ante reasons for starting a business influence ex post labor and capital allocations in a meaningful way suggests that goals need to be included more frequently in theoretical and empirical analyses of entrepreneurship. In much of the economics and economics-related theory literatures, the entry and exit of firms is modeled mechanically rather than behaviorally. Formally including entrepreneurial motivations into models with entry and exit would greatly extend our ability to analyze these processes and at the same time provide alternative explanations for "non-entrepreneurial" behavior such as the persistence of underperforming firms (Gimeno et al., 1997; DeTienne et al., 2008) and the failure of many established new firms to grow or innovate (Hurst and Pugsley, 2011).

If goals have a meaningful impact on entrepreneurial decisions as our results suggest, more empirical models should include them as well -- typically as independent variables along 
with other entrepreneur descriptors such as gender, age, ethnicity, and education. A recent line of papers, for example, focuses on entrepreneur expectations as an intervening variable between past business experience and future business activity (Ucbasaran et al., 2009; Ucbasaran et al., 2010; Townsend et al., 2010). Entrepreneur goals are not considered in these studies, and thus a logical extension would be to include them explicitly in the explanatory framework. Goals could be modeled as intervening between experience and expectations, as influencing future business activity in parallel with expectations, as intervening between expectations and activity, or as exerting some combination of such influences. Whatever the specific approach, we believe the inclusion of goal variables would provide a more realistic representation of how entrepreneurs make decisions.

\subsubsection{Policy}

The empirical results presented in this paper are based on the work of earlier scholars showing that the majority of entrepreneurs start businesses for nonmonetary reasons. They demonstrate that goals are behaviorally meaningful in general and, more specifically, that entrepreneurs with nonmonetary goals use relatively more own and family labor than do those with monetary goals. These findings suggest that policy-makers seeking to promote entrepreneurship in the economy need to base their recommendations on a more nuanced view of the entrepreneurial process. We make three points in this regard.

The first concerns tax policy. The importance of small businesses in the national economy is well-document and often cited in debates about the effect of tax rate changes on entrepreneurial entry and hiring. Our results indicate that such effects are likely to be less important, at least in the short run, than is often assumed because taxes will matter most to entrepreneurs with monetary goals and these represent less than $50 \%$ of all entrepreneurs. With 
regard to entry, it is well-established that the majority of nascent entrepreneurs have nonmonetary primary goals (Reynolds and Curtin, 2008) and thus are unlikely to be influenced much by tax changes in deciding whether or not to take the plunge. Recent research using micro-datasets has found that tax effects on entrepreneurial entry are relatively weak (Bruce and Mohsin, 2006). The present study demonstrates the behavioral significance of nonmonetary goals and thus provides one possible explanation for these findings. Concerning new firm hiring, our econometric results show a negative association between having a nonmonetary goal and hiring non-family employees. Since most new firm owners have nonmonetary goals (Table 3), this finding points to the likelihood that tax changes will again have a significant effect on only a minority of firms and thus that their overall impact on new firm hiring will be limited.

Our second point is a cautionary note regarding the design of programs to promote entrepreneurship. Mass media coverage of entrepreneurship often promotes the view that it is primarily about making money -- and also, more indirectly, that it should be about making money. However, because so many entrepreneurs launch new businesses for nonmonetary reasons -- including, today, social entrepreneurs (Dacin et al., 2010) -- it is important that the incentive and support structures provided by such programs not be exclusively focused on the possibilities for pecuniary gain. Such an approach might be discouraging to potential new entrants with strong nonmonetary motivations and also to at least some of those with monetary motivations, many of whom will have nonmonetary secondary goals which could help sustain them during the lean post-startup period.

Third, our research indicates the need for a broader range of success indicators than is customarily used in entrepreneurial policy analysis. Because it shows that individuals become entrepreneurs for a variety of reasons and that they run their firms in accord with those reasons, it 
suggests that the standard objective indicators -- survival, growth, profits, etc. -- need to be supplemented by other, more subjective indicators that measure the personal satisfaction obtained from the entrepreneurial experience. For example, just because a firm closes after a few years or survives for a longer period but does not grow, doesn't necessarily mean it is a "failed" business. Some entrepreneurs have relatively short time horizons and choose to exit early (for example, those starting a business in retirement or as a stepping-stone to future employment). Others with longer time horizons do not pursue growth strategies because they wish to live the "quiet life" (Hurst and Pugsley, 2011). Conventional measures of success often misclassify such cases.

\subsection{Limitations and Directions for Future Research}

Like every study, this one has limitations which suggest directions for future research. The first is the age of the NFIB data. Although we believe our findings apply to current entrepreneur behavior, we acknowledge concerns that the nature of the goal-input linkage may have changed over time. Re-estimation of our input relationships is therefore called for once more contemporary data become available. Second, our analysis focuses only on short-run behavior. Our firms were in business for less than 18 months at the time their owners filled out the NFIB questionnaire. A natural follow-up question is whether initial goals continue to affect entrepreneur decisions in businesses that survive beyond this early stage. On the one hand, the owner's initial goals may help establish an organizational culture which persists through time. On the other, changing circumstances may make such goals irrelevant. Only empirical investigation can determine which effect is more important. Third, because our focus is on the actions of very young firms we do not investigate the effect of goal differences on entrepreneurial outcomes such as survival, profitability, and growth. Despite our reservations 
(noted above) about using such objective measures as the sole indicators of success, it is clear that examining the effect of goals on outcomes is a natural extension of the present research. Fourth, our conclusions can be applied only to U.S. entrepreneurs. For many reasons, one would expect the psychology of entrepreneurship to be different in different societies, both with regard to the specific motivations for starting businesses and the effects such motivations have on behavior. There is already a literature on the first of these topics. This work should be extended to address the second. 


\section{Appendix}

The purpose of this appendix is to provide a more formal description of the entrepreneur production and utility functions that underlie the conceptual framework described in Section 4. The production function for the representative entrepreneur in industry i can be represented as follows:

$$
\begin{aligned}
& \qquad \mathrm{Q}={ }^{\mathrm{i}} \mathrm{f}\left(\mathrm{L}_{0}, \mathrm{~L}_{\mathrm{F}}, \mathrm{L}_{\mathrm{E}}, \mathrm{K} ; \mathrm{Y}_{1}, \ldots, \mathrm{Y}_{\mathrm{n}}\right) \text {, where } \\
& \mathrm{Q}=\text { output quantity } \\
& \mathrm{L}_{0}=\text { owner labor input } \\
& \mathrm{L}_{\mathrm{F}}=\text { family labor input } \\
& \mathrm{L}_{\mathrm{E}}=\text { employee labor input } \\
& \mathrm{K}=\text { capital } \\
& \mathrm{Y}^{\prime} \text { 's = entrepreneur human capital measures. }
\end{aligned}
$$

Owner and family labor are unpaid. Because the entrepreneur is an owner-manager, it is assumed he maximizes utility rather than (accounting) profit. It is necessary, therefore, to specify a utility function for him as well as a production function. This relationship has two significant features for the purposes of the study. First, it is indexed $(j=1,2,3.4,5)$ according to the entrepreneur's primary goal and, second, its arguments are the input quantities and accounting profit $(\pi)$ :

$$
\mathrm{U}={ }^{\mathrm{j}} \mathrm{g}\left(\mathrm{L}_{0}, \mathrm{~L}_{\mathrm{F}}, \mathrm{L}_{\mathrm{E}}, \mathrm{K}, \pi\right) \text {. }
$$

The entrepreneur's decision variables are the four input quantities. Maximization of utility subject to the production function and exogenous prices (input and output) yields input quantities that depend (among other things) on the entrepreneur's primary goal. 


\section{References}

Åstebro, Thomas and Thompson, Peter (2011). "Entrepreneurs: Jacks of All Trades or Hobos?" Research Policy, Vol. 40, Issue 5, June, 637-649.

Birley, Sue and Westhead, Paul (1994). "A Taxonomy of Business Start-Up Reasons and Their Impact on Firm Growth and Size," Journal of Business Venturing, Vol. 9, Issue 1, January, 7-31.

Bruce, Donald and Mohsin, Mohammed (2006). "Tax Policy and Entrepreneurship: New Time Series Evidence,” Small Business Economics, Vol. 26, Nos. 4-5, December, 409-425.

Buttner, E. Holly and Moore, Dorothy (1997). "Women's Organizational Exodus to Entrepreneurship: Self-Reported Motivations and Correlates with Success," Journal of Small Business Management, Vol. 35, No. 1, January, 34-46.

Campbell, Karen (2009). "Entrepreneurial Behavior and the Development of Trading Institutions: An Analytical Approach," Journal of Institutional and Theoretical Economics, Vol. 65, No. 3, September, 487-507.

Carter, Nancy (1997). "Entrepreneurial Processes and Outcomes: The Influence of Gender," in Reynolds, P. and White, S. (eds.), The Entrepreneurial Process (Westport, CT: Quorum Books).

Carter, Nancy; Gartner, William; Shaver, Kelly; and Gatewood, Elizabeth (2003). "The Career Reasons of Nascent Entrepreneurs," Journal of Business Venturing, Vol. 18, Issue 1, January, 13-39.

Cassar, Gavin and Craig, Justin (2009). "An Investigation of Hindsight Bias in Nascent Venture Activity," Journal of Business Venturing, Vol. 24, Issue 2, March, 149-164.

Choo, Stephen and Wong, Melvin (2006). "Entrepreneurial Intentions: Triggers and Barriers to New Venture Creations in Singapore," Singapore Management Review, Vol. 28, No. 2, $2^{\text {nd }}$ half, 47-64.

Chua, Jess; Christman, James; Kellermanns, Franz; and Wu, Zhenyu (2011). "Family Involvement and New Venture Debt Financing," Journal of Business Venturing, Vol. 26, Issue 4, July, 472-488.

Cooper, Arnold and Dunkelberg, William (1986). "Entrepreneurship and Paths to Business Ownership," Strategic Management Journal, Vol. 7, No. 1, January/March, 53-68.

Cooper, Arnold; Dunkelberg, William; Woo, Carolyn; and Dennis, William (1990). New Business in America: The Firms and Their Owners (Washington, DC: The NFIB Foundation).

Cooper, Arnold; Gimeno-Gascon, F. Javier; and Woo, Carolyn (1994). "Initial Human Capital and Financial Capital as Predictors of New Venture Performance," Journal of Business Venturing, Vol. 9, Issue 5, September, 371-395. 
Dacin, Peter; Dacin, M. Tina; and Matear, Margaret (2010). "Social Entrepreneurship: Why We Don't Need a New Theory and How We Move Forward From Here," Academy of Management Perspectives, Vol. 24, No. 3, August, 37-57.

DeTienne, Dawn; Shepherd, Dean; and De Castro, Julio (2008). "The Fallacy of 'Only the Strong Survive': The Effects of Extrinsic Motivation on the Persistence Decisions for UnderPerforming Firms," Journal of Business Venturing, Vol. 23, Issue 5, September, 528-546.

Douglas, Evan and Shepherd, Dean (1999). "Entrepreneurship as a Utility Maximizing Response," Journal of Business Venturing, Vol. 15, Issue 3, May, 231-251.

Dunkelberg, William and Cooper, Arnold (1982). "Entrepreneurial Typologies: An Empirical Study," in Vesper, K. (ed.), Frontiers of Entrepreneurship Research (Wellesley, MA: Babson College).

Dunkelberg, William and Scott, Jonathan (2011). "The Changing Landscape of Small-Firm Finance," in R. Yazdipour (ed.), Advances in Entrepreneurial Finance: With Applications from Behavioral Finance and Economics (New York, NY: Springer).

Errington, Andrew and Gasson, Ruth (1994). "Labour Use in the Family Farm Business," Sociologia Ruralis, Vol. 34, No. 4, December, 293-307.

Formby, John and Millner, Edward (1985). "The Convergence of Utility and Profit Maximization," Southern Economic Journal, Vol. 51, no. 4, April, 1174-1185.

Gartner, William (1989). “'Who is an Entrepreneur?' Is the Wrong Question," Entrepreneurship Theory and Practice, Vol. 13, Issue 4, Summer, 47-68.

Gatewood, Elizabeth; Shaver, Kelly; and Gartner, William (1995). "A Longitudinal Study of Cognitive Factors Influencing Start-Up Behaviors and Success at Venture Creation," Journal of Business Venturing, Vol. 10, Issue 5, September, 371-391.

Gimeno, Javier; Folta, Timothy; Cooper, Arnold; and Woo, Carolyn (1997). "Survival of the Fittest? Entrepreneurial Human Capital and the Persistence of Underperforming Firms," Administrative Science Quarterly, Vol. 42, No. 4, December, 528-546.

Graves, Samuel and Langowitz, Nan (1996). "R\&D Productivity: A Global Multi-Industry Comparison," Technological Forecasting and Social Change, Vol. 53, Issue 2, October, 125 137.

Greene, William (2007). Econometric Analysis, $6^{\text {th }}$ ed. (Prentice Hall, Upper Saddle River, NJ).

Hamilton, Barton (2000). "Does Entrepreneurship Pay? An Empirical Analysis of the Returns to Self-Employment," Journal of Political Economy, Vol. 108, No. 3, June, 604-631. 
Hambrick, Donald (2007). "Upper Echelons Theory: An Update," Academy of Management Review, Vol. 32, No. 2, April, 334-343.

Hannan, Timothy (1982). "On the Equivalence of Profit Maximization and Utility Maximization by an Owner-Manager: Comment," Southern Economic Journal, Vol. 49, No. 1, July, 255-259.

Henderson, James and Quandt, Richard (1980). Microeconomic Theory: A Mathematical Approach, $3^{\text {rd }}$ ed. (New York: McGraw-Hill).

Hurst, Erik and Pugsley, Benjamin (2011). "Understanding Small Business Heterogeneity," Working Paper 239, George Stigler Center for the Study of the Economy and the State, University of Chicago, April.

Kaufmann, Patrick (1999). "Franchising and the Choice of Self-Employment," Journal of Business Venturing, Vol. 14, Issue 4, July, 345-362.

Kepler, Erin and Shane, Scott (2007). "Are Male and Female Entrepreneurs Really That Different?” Office of Advocacy, Small Business Administration, September.

Knight, Frank (1921). Risk, Uncertainty, and Profit (Boston: Houghton Mifflin).

Kolvereid, Lars (1996). "Organizational Employment Versus Self-Employment: Reasons for Career Choice Intentions," Entrepreneurship Theory and Practice, Vol. 20, Issue 3, Spring, 2331.

Krueger, Norris; Reilly, Michael; and Carsrud, Alan (2000). "Competing Models of Entrepreneurial Intentions," Journal of Business Venturing, Vol. 15, Issue 5/6, SeptemberNovember, 411-432.

Kuratko, Donald; Hornsby, Jeffrey; and Naffziger, Douglas (1997). “An Examination of Owner's Goals in Sustaining Entrepreneurship," Journal of Small Business Management, Vol. 35, No. 1, January, 24-33.

Levesque, Moren; Shepherd, Dean; and Douglas, Evan (2002). "Employment or SelfEmployment? A Dynamic Utility-Maximizing Model," Journal of Business Venturing, Vol. 17, Issue 3, May, 189-210.

Minniti, Maria and Levesque, Moren (2008). "Recent Developments in the Economics of Entrepreneurship," Journal of Business Venturing, Vol. 23, Issue 6, November, 603-612.

Moore, Carmen (2007). The Role of Owner Motivation in Resource Allocation, Firm Performance, and Satisfaction: The Case of New Entrepreneurial Ventures, unpublished doctoral dissertation, Department of Economics, Temple University.

Morton, Fiona and Podolny, Joel (2002). "Love or Money? The Effects of Owner Motivation in the California Wine Industry," The Journal of Industrial Economics, Volume L, No. 4, December, 431-456. 
Moskowitz, Tobias and Vissing-Jorgensen, Annette (2002). "The Returns to Entrepreneurial Investment: A Private Equity Premium Puzzle?" The American Economic Review, Vol. 92, No. 4, September, 745-778.

Naffziger, Douglas; Hornsby, Jeffrey; and Kuratko, Donald (1994). “A Proposed Research Model of Entrepreneurial Motivation," Entrepreneurship Theory and Practice, Vol. 18, Issue 3, Spring, 29-42.

Olsen, Jr., E. Odgers (1977). "Profit Maximization vs. Utility Maximization: A Correction," Southern Economic Journal, Vol. 43, No. 3, January, 1390-1393.

Parker, Simon (2004). The Economics of Self-Employment and Entrepreneurship (Cambridge, UK: Cambridge University Press).

Reynolds, Paul (2000). "National Panel Study of U.S. Business Start-ups: Background and Methodology," in Katz, J. (Ed.), Advances in Entrepreneurship, Firm Emergence and Growth, Vol. 4 (Stamford, CT: JAI Press).

Reynolds, Paul and Curtin, Richard (2008). "Business Creation in the United States: Panel Study of Entrepreneurial Dynamics II Initial Assessment," Foundations and Trends in Entrepreneurship, Vol. 4, No. 3, 155-307.

Santarelli, Enrico and Vivarelli, Marco (2006). "Entrepreneurship and the Process of Firms' Entry, Survival, and Growth," IZA Discussion Paper 2475, Bonn, Germany, December.

Sarasvathy, Saras (2004). "Making It Happen: Beyond Theories of the Firm to Theories of Firm Design," Entrepreneurship Theory and Practice, Vol. 28, Issue 6, Winter, 519-531.

Scheinberg, Sari and MacMillan, Ian (1988). "An 11 Country Study of Motivation to Start a Business," in Kirchoff, B.; Long, W.; McMullan, W.; Vesper, K.; and Wetzel, W. (Eds.), Frontiers of Entrepreneurship Research (Wellesley, MA: Babson College).

Schumpeter, Joseph (1912). The Theory of Economic Development (Cambridge, MA: Harvard University Press, Trans. R. Opie, 1934).

Scitovsky, Tibor (Scitovszky, Tibor De) (1943). "A Note on Profit Maximization and its Implications, The Review of Economic Studies, Vol. 11, No. 1, Winter, 57-60.

Shane, Scott and Venkataraman, S. (2000). "The Promise of Entrepreneurship as a Field of Research," The Academy of Management Review, Vol. 25, No. 1, January, 217-226.

Shane, Scott; Kolvereid, Lars; and Westhead, Paul (1991). "An Exploratory Examination of the Reasons Leading to New Firm Formation Across Country and Gender," Journal of Business Venturing, Vol. 6, Issue 6, November, 431-446.

Shaver, Kelly; Gartner, William; Crosby, Elizabeth; Bakalarova; and Gatewood, Elizabeth (2001). "Attributions About Entrepreneurship: A Framework and Process for Analyzing Reasons for Starting a Business," Entrepreneurship Theory and Practice, Vol. 26, Issue 2, Winter, 5-32. 
Singell Jr., Larry and Thornton, James (1997). "Nepotism, Discrimination, and the Persistence of Utility-Maximizing, Owner-Operated Firms," Southern Economic Journal, Vol. 63, No. 4, April, 904-919.

Smith, Adam (1776). An Inquiry into the Nature and Causes of the Wealth of Nations (London: W. Strahan and T. Cadell).

Stewart, Wayne, Jr.; Carland, Jo Ann; Carland, James; Watson, Warren; and Sweo, Robert (2003). "Entrepreneurial Dispositions and Goal Orientations: A Comparative Exploration of United States and Russia," Journal of Small Business Management, Vol.4, No. 1, January, 27-46.

Townsend, David; Busenitz, Lowell; and Arthurs, Jonathan (2010). "To Start or Not to Start: Outcome and Ability Expectations in the Decision to Start a New Venture," Journal of Business Venturing, Vol. 25, Issue 2, March, 192-202.

Ucbasaran, Denis; Westhead, Paul; and Wright, Mike (2009). "The Extent and Nature of Opportunity Identification by Experienced Entrepreneurs," Journal of Business Venturing, Vol. 24, Issue 2, March, 99-115.

Ucbasaran, Deniz; Westhead, Paul; Wright, Mike; and Flores, Manuel (2010). "The Nature of Entrepreneurial Experience, Business Failure, and Comparative Optimism," Journal of Business Venturing, Vol. 25, Issue 6, November, 541-555.

U.S. Department of Commerce, Bureau of Economic Analysis (1985). Regional Economic Information System, Table CA25, http://www.ciesin.org/datasets/reis/var.list.bea.html.

Watson, Warren; Stewart, Wayne; and BarNir, Anat (2003). "The Effects of Human Capital and Organizational Demography, and Interpersonal Processes on Venture Partner Perceptions of Firm Growth and Profit," Journal of Business Venturing, Vol. 18, Issue 2, March, 145-163.

Westhead, Paul; Wright, Mike; and Ucbasaran, Deniz (2001). "The Internationalization of New and Small Firms: A Resource-Based View," Journal of Business Venturing, Vol. 16, Issue 4, July, 333-358.

Woo, Carolyn; Cooper, Arnold; and Dunkelberg, William (1991). "The Development and Interpretation of Entrepreneurial Typologies," Journal of Business Venturing, Vol. 6, Issue 1, March, 93-114.

Wooldridge, Jeffrey (2002). Econometric Analysis of Cross Section and Panel Data (Cambridge, MA: The MIT Press). 
Table 1

Owner and business characteristics for 2,944 respondents

\begin{tabular}{|c|c|c|c|}
\hline Owner Characteristics & $\%$ & Business characteristics & $\%$ \\
\hline Age & & Entrepreneurial mode & \\
\hline 24 and less & 9 & Started the business & 67 \\
\hline 25 to 35 & 43 & Purchased the business & 28 \\
\hline 36 to 54 & 44 & Inherited the business & 2 \\
\hline 55 and over & 4 & Brought in or promoted & 3 \\
\hline Sex & & Industry & \\
\hline Female & 21 & Construction & 9 \\
\hline \multirow[t]{2}{*}{ Male } & 79 & Manufacturing & 8 \\
\hline & & Transportation & 3 \\
\hline \multicolumn{2}{|l|}{ Racial minority } & Wholesale & 5 \\
\hline Yes & 6 & Retail & 43 \\
\hline \multirow[t]{2}{*}{ No } & 94 & Agriculture & 2 \\
\hline & & Financial & 5 \\
\hline \multicolumn{2}{|l|}{ Education } & Service & 19 \\
\hline Less than high school & 7 & Professional & 6 \\
\hline High school & 33 & & \\
\hline Less than BS/BA & 33 & Region & \\
\hline Bachelor's degree & 17 & New England & 4 \\
\hline Some graduate school & 4 & Mid-Atlantic & 10 \\
\hline \multirow[t]{2}{*}{ Advanced degree } & 6 & Great Lakes & 15 \\
\hline & & Plains & 11 \\
\hline \multicolumn{2}{|l|}{ Business experience } & Southeast & 18 \\
\hline Never owned a business & 75 & Southwest & 16 \\
\hline \multirow[t]{2}{*}{ Owned a business } & 25 & Mountain & 7 \\
\hline & & Far West & 20 \\
\hline \multicolumn{4}{|l|}{ Parents owned a firm } \\
\hline Yes & 45 & & \\
\hline No & 54 & Partners & \\
\hline \multirow[t]{2}{*}{ No answer } & 1 & None & 71 \\
\hline & & 1 & 20 \\
\hline \multicolumn{2}{|l|}{ Highest level of management experience } & 2 to 4 & 8 \\
\hline Worker & 19 & 5 and over & 1 \\
\hline Supervisor & 39 & & \\
\hline Manager & 11 & Time between first expenditure and sale & \\
\hline Managed own firm & 26 & $1-3$ months & 87 \\
\hline Other & 4 & 4-6 months & 6 \\
\hline \multirow[t]{2}{*}{ No answer } & 1 & Over 6 months & 3 \\
\hline & & No answer & 4 \\
\hline
\end{tabular}


Table 2

Input measure distributions and summary statistics

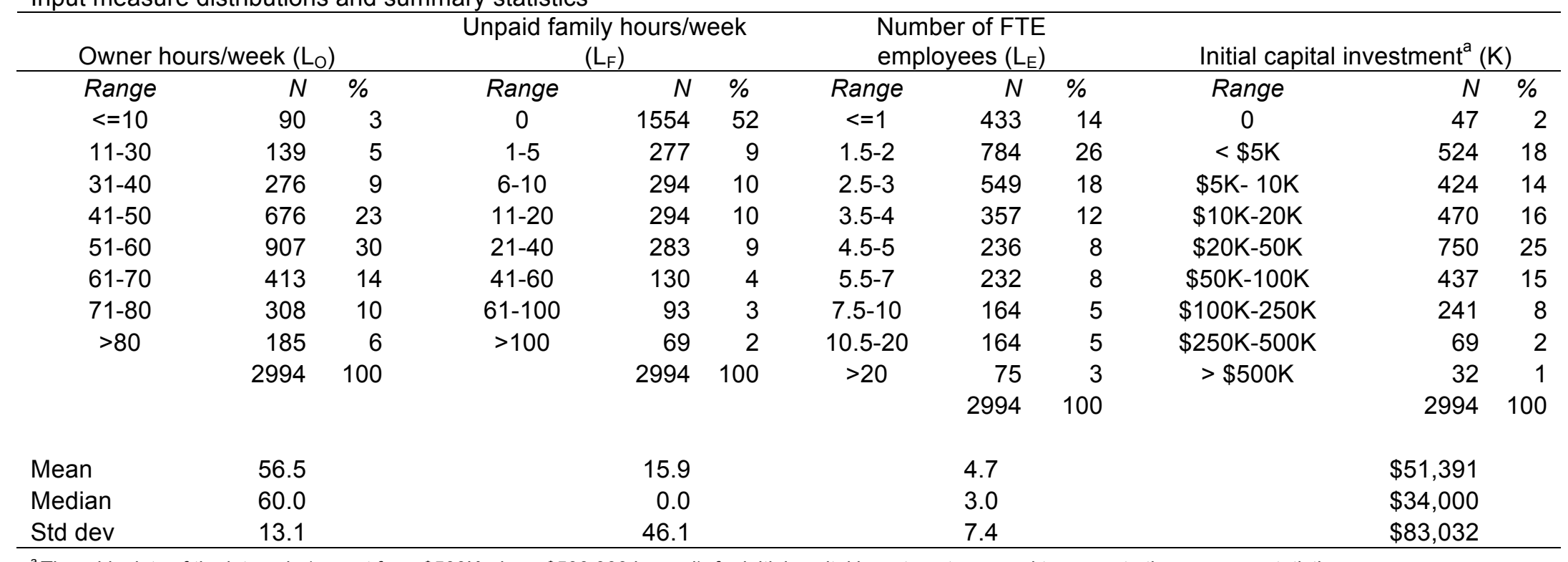

${ }^{a}$ The midpoints of the intervals (except for $>\$ 500 \mathrm{~K}$ where $\$ 500,000$ is used) for initial capital investment are used to compute the summary statistics. 
Table 3

Primary goals

\begin{tabular}{lrr}
\hline Goal name & $\mathrm{N}$ & $\%$ \\
\hline Make money (MO) & 878 & 29.3 \\
Do work I want to do (WK) & 759 & 25.4 \\
Avoid working for others (AV) & 530 & 17.7 \\
Build successful organization (BU) & 522 & 17.4 \\
Other/no response (OT) & 305 & 10.2 \\
& 2994 & 100.0
\end{tabular}


Table 4

Control variable summary statistics

\begin{tabular}{|c|c|c|}
\hline Variable & Mean & Std. dev. \\
\hline Partners: $0^{*}$ & 0.693 & 0.461 \\
\hline Partners $>0$ & 0.307 & 0.461 \\
\hline Non-startup: no & 0.636 & 0.481 \\
\hline Non-startup: yes* & 0.364 & 0.481 \\
\hline Management experience: yes & 0.763 & 0.425 \\
\hline Owner age: $<30$ & 0.262 & 0.440 \\
\hline Owner age: $30-39$ & 0.391 & 0.488 \\
\hline Owner age: $40-49$ & 0.238 & 0.426 \\
\hline Owner age: $>49$ & 0.109 & 0.311 \\
\hline Less than high school & 0.074 & 0.262 \\
\hline High school diploma & 0.342 & 0.475 \\
\hline Some college & 0.337 & 0.473 \\
\hline Bachelor's degree* & 0.159 & 0.366 \\
\hline Graduate school & 0.088 & 0.284 \\
\hline Previous jobs: 0 & 0.046 & 0.210 \\
\hline Previous jobs: $1-2^{*}$ & 0.264 & 0.441 \\
\hline Previous jobs: 3-4 & 0.345 & 0.475 \\
\hline Previous jobs: 5-6 & 0.194 & 0.396 \\
\hline Previous jobs: 7-9 & 0.077 & 0.267 \\
\hline Previous jobs: $>9$ & 0.074 & 0.262 \\
\hline No. of bus classes: $0^{*}$ & 0.402 & 0.490 \\
\hline No. of bus. classes: $1-2$ & 0.227 & 0.419 \\
\hline No. of bus classes: 3-6 & 0.184 & 0.388 \\
\hline No. of bus classes: $>6$ & 0.186 & 0.389 \\
\hline Previously owned firm & 0.290 & 0.454 \\
\hline Parents owned firm & 0.446 & 0.497 \\
\hline Construction & 0.073 & 0.260 \\
\hline Manufacturing & 0.078 & 0.268 \\
\hline Transportation & 0.024 & 0.154 \\
\hline Wholesale & 0.042 & 0.202 \\
\hline Retail $^{*}$ & 0.459 & 0.498 \\
\hline Agriculture & 0.021 & 0.142 \\
\hline Finance & 0.049 & 0.215 \\
\hline Services & 0.192 & 0.394 \\
\hline Profession & 0.054 & 0.226 \\
\hline New England & 0.036 & 0.186 \\
\hline Mid-Atlantic & 0.100 & 0.300 \\
\hline Great Lakes & 0.143 & 0.350 \\
\hline Plains & 0.119 & 0.324 \\
\hline Southeast & 0.179 & 0.383 \\
\hline Southwest & 0.161 & 0.368 \\
\hline Mountain & 0.068 & 0.253 \\
\hline
\end{tabular}


$\begin{array}{lll}\text { Far west* }^{*} & 0.193 & 0.395\end{array}$

$\begin{array}{lll}\text { Industry-region wage } & 17.687 & 6.276\end{array}$

* Indicates the omitted category in the regression analysis 
Table 5

Estimation results for hypothesis $1^{\mathrm{a}}$

\begin{tabular}{|c|c|c|c|c|c|c|c|c|c|c|c|c|}
\hline \multirow[b]{2}{*}{ Variable } & \multicolumn{2}{|c|}{$\begin{array}{l}\text { Owner hours } \\
\text { Worked }\left(L_{O}\right)\end{array}$} & & \multicolumn{2}{|c|}{$\begin{array}{l}\text { Unpaid family } \\
\text { hours }\left(L_{F}\right)\end{array}$} & & \multicolumn{2}{|c|}{$\begin{array}{c}\text { No. of FTE } \\
\text { Employees }\left(L_{E}\right)\end{array}$} & & \multicolumn{2}{|c|}{$\begin{array}{c}\text { Initial capital } \\
\text { investment }(\mathrm{K})\end{array}$} & \\
\hline & $\begin{array}{l}\text { Coeffi- } \\
\text { cient }\end{array}$ & $\begin{array}{l}\text { Std. } \\
\text { Err. }\end{array}$ & & $\begin{array}{c}\text { Coeffi- } \\
\text { cient }\end{array}$ & $\begin{array}{l}\text { Std. } \\
\text { Err. }\end{array}$ & & $\begin{array}{l}\text { Coeffi- } \\
\text { cient }\end{array}$ & $\begin{array}{l}\text { Std. } \\
\text { Err. }\end{array}$ & & $\begin{array}{l}\text { Coeffi- } \\
\text { cient }\end{array}$ & $\begin{array}{l}\text { Std. } \\
\text { Err. }\end{array}$ & \\
\hline \multicolumn{13}{|l|}{ Primary Goals } \\
\hline davoid & 0.006 & 0.023 & & 0.482 & 0.169 & *** & -0.063 & 0.027 & ** & 0.022 & 0.082 & \\
\hline dwork & 0.035 & 0.021 & * & 0.138 & 0.156 & & -0.067 & 0.043 & & 0.004 & 0.096 & \\
\hline dbuild & 0.045 & 0.016 & *** & 0.164 & 0.062 & 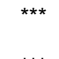 & 0.088 & 0.068 & & 0.196 & 0.106 & * \\
\hline dother & 0.051 & 0.010 & ${ }^{* * *}$ & 0.524 & 0.114 & *** & -0.066 & 0.095 & & 0.175 & 0.155 & \\
\hline \multicolumn{13}{|l|}{ Controls } \\
\hline Non-startup & 0.006 & 0.020 & & -0.131 & 0.152 & & -0.294 & 0.036 & ${ }^{* * *}$ & 0.736 & 0.075 & ${ }^{* * *}$ \\
\hline Partners & -0.019 & 0.012 & & -0.122 & 0.138 & & 0.258 & 0.084 & *** & 0.242 & 0.057 & *** \\
\hline Management experience & 0.042 & 0.018 & ** & 0.033 & 0.073 & & 0.341 & 0.039 & ${ }^{* * *}$ & 0.281 & 0.085 & *** \\
\hline Owner age: $<30$ & 0.104 & 0.017 & $* * *$ & -0.280 & 0.111 & *** & 0.025 & 0.088 & & -0.374 & 0.106 & *** \\
\hline Owner age: $30-39$ & 0.071 & 0.023 & $* \star *$ & -0.274 & 0.106 & & 0.092 & 0.100 & & -0.188 & 0.210 & \\
\hline Owner age: $40-49$ & 0.047 & 0.034 & & -0.156 & 0.126 & & 0.155 & 0.057 & *** & -0.155 & 0.151 & \\
\hline Less than high school & 0.071 & 0.017 & *** & 0.434 & 0.272 & * & 0.019 & 0.070 & & -0.657 & 0.185 & *夫* \\
\hline High school diploma & 0.011 & 0.013 & & 0.187 & 0.123 & * & -0.047 & 0.058 & & -0.357 & 0.175 & ** \\
\hline Some college & 0.004 & 0.007 & & -0.007 & 0.068 & & -0.016 & 0.059 & & -0.244 & 0.127 & * \\
\hline Graduate school & -0.003 & 0.033 & & 0.130 & 0.102 & & 0.100 & 0.113 & & 0.419 & 0.188 & ** \\
\hline Previous jobs: 0 & -0.013 & 0.013 & & 0.102 & 0.108 & & 0.125 & 0.162 & & -0.174 & 0.173 & \\
\hline Previous jobs: $3-4$ & 0.006 & 0.010 & & 0.322 & 0.079 & *** & 0.039 & 0.031 & & -0.013 & 0.076 & \\
\hline Previous jobs: 5-6 & 0.049 & 0.013 & $* \star *$ & 0.255 & 0.068 & *** & -0.052 & 0.033 & & -0.063 & 0.125 & \\
\hline Previous jobs: 7-9 & 0.051 & 0.017 & $* * *$ & 0.074 & 0.167 & & -0.165 & 0.078 & ** & -0.140 & 0.100 & \\
\hline Previous jobs: >= 10 & 0.105 & 0.025 & *** & 0.245 & 0.180 & & -0.192 & 0.086 & ** & -0.497 & 0.131 & *** \\
\hline No. of bus classes: $1-2$ & -0.021 & 0.011 & * & -0.112 & 0.182 & & -0.061 & 0.032 & & 0.139 & 0.038 & *** \\
\hline No. of bus classes: 3-6 & 0.006 & 0.008 & & 0.040 & 0.050 & & 0.110 & 0.083 & & 0.146 & 0.070 & ** \\
\hline No. of bus classes: $>6$ & 0.008 & 0.016 & & 0.006 & 0.062 & & 0.233 & 0.077 & *** & 0.360 & 0.143 & *** \\
\hline Previously owned firm & 0.015 & 0.007 & ** & 0.125 & 0.066 & ** & 0.156 & 0.049 & *** & 0.234 & 0.111 & ** \\
\hline Parents owned firm & -0.013 & 0.005 & ** & 0.208 & 0.098 & ** & -0.022 & 0.029 & & -0.054 & 0.042 & \\
\hline
\end{tabular}




\begin{tabular}{|c|c|c|c|c|c|c|c|c|c|c|}
\hline Industry controls & Yes & & & Yes & & & Yes & & & Yes \\
\hline Region controls & Yes & & & Yes & & & Yes & & & Yes \\
\hline Wage control & Yes & & & Yes & & & Yes & & & Yes \\
\hline Constant & 3.920 & 0.047 & *** & 2.713 & 0.918 & *** & 2.583 & 0.263 & *** & \\
\hline Alpha & 0.140 & 0.014 & $x * *$ & 6.180 & 0.559 & *** & 0.563 & 0.048 & *** & \\
\hline $\begin{array}{l}\text { Wald linear restriction test: } \\
\text { davoid=dwork = dbuild } \\
=\text { dother }=0[\times 2(4)]\end{array}$ & 44.8 & $* * *$ & & 186.350 & *** & & 11.270 & *** & & 7.420 \\
\hline
\end{tabular}

* Indicates significant at the .10 level; ** at the .05 level; and ${ }^{* * *}$ at the .01 level

a Negative binomial regression was used for the three labor equations and ordered probit for the capital equation. 
Table 6

Motivating goal marginal effect results for Hypothesis 2

\begin{tabular}{|c|c|c|c|}
\hline Dependent variable & $\mathrm{dy} / \mathrm{dx} \mathrm{x}^{\mathrm{a}}$ & Std Err & \\
\hline \multicolumn{4}{|c|}{ Owner hours worked $\left(\mathrm{L}_{0}\right)$} \\
\hline davoid & 0.313 & 1.274 & \\
\hline dwork & 2.004 & 1.218 & * \\
\hline dbuild & 2.569 & 0.941 & *** \\
\hline dother & 2.910 & 0.595 & $* * *$ \\
\hline \multicolumn{4}{|c|}{ Unpaid family hours $\left(L_{F}\right)$} \\
\hline davoid & 7.953 & 3.265 & ** \\
\hline dwork & 2.000 & 2.340 & \\
\hline dbuild & 2.368 & 0.922 & $\star \star \star *$ \\
\hline dother & 9.131 & 2.433 & $* \star \star$ \\
\hline \multicolumn{4}{|c|}{ No. of FTE Employees ( $\left.L_{E}\right)$} \\
\hline davoid & -0.536 & 0.226 & ** \\
\hline dwork & -0.571 & 0.359 & \\
\hline dbuild & 0.769 & 0.606 & \\
\hline dother & -0.558 & 0.775 & \\
\hline
\end{tabular}

${ }^{a} \mathrm{dy} / \mathrm{dx}$ is the derivative of the input resource variable for a discrete change of the primary goal dummy variable from 0 to 1 evaluated at the mean of each resource input variable

* Indicates significant at the .10 level; ${ }^{* *}$ at the .05 level; and ${ }^{* *}$ at the .01 level 
Table 7

Robustness test

\begin{tabular}{|c|c|c|c|c|c|c|c|c|c|c|c|c|}
\hline \multirow[b]{2}{*}{ Variable } & \multicolumn{2}{|c|}{$\begin{array}{l}\text { Owner hours } \\
\text { Worked }\left(L_{\circ}\right)\end{array}$} & & \multicolumn{2}{|c|}{$\begin{array}{l}\text { Unpaid family } \\
\text { hours }\left(L_{F}\right)\end{array}$} & & \multicolumn{2}{|c|}{$\begin{array}{c}\text { No. of FTE } \\
\text { Employees }\left(L_{E}\right)\end{array}$} & \multicolumn{4}{|c|}{$\begin{array}{c}\text { Initial capital } \\
\text { investment }(\mathrm{K})\end{array}$} \\
\hline & $\begin{array}{c}\text { Coeffi- } \\
\text { cient }\end{array}$ & $\begin{array}{l}\text { Std. } \\
\text { Err. }\end{array}$ & & $\begin{array}{c}\text { Coeffi- } \\
\text { cient }\end{array}$ & $\begin{array}{l}\text { Std. } \\
\text { Err. }\end{array}$ & & $\begin{array}{c}\text { Coeffi- } \\
\text { cient }\end{array}$ & $\begin{array}{l}\text { Std. } \\
\text { Err. }\end{array}$ & & $\begin{array}{c}\text { Coeffi- } \\
\text { cient }\end{array}$ & $\begin{array}{l}\text { Std. } \\
\text { Err. }\end{array}$ & \\
\hline \multicolumn{13}{|l|}{ Primary goals } \\
\hline davoid & 0.009 & 0.022 & & 0.211 & 0.131 & & -0.072 & 0.044 & * & 0.005 & 0.133 & \\
\hline dwork & 0.012 & 0.017 & & 0.132 & 0.201 & & -0.171 & 0.042 & *** & 0.009 & 0.160 & \\
\hline dbuild & 0.057 & 0.014 & $* \star *$ & 0.278 & 0.080 & *** & -0.029 & 0.061 & & 0.287 & 0.179 & \\
\hline dother & 0.044 & 0.015 & ${ }^{* * *}$ & 0.699 & 0.144 & *** & -0.177 & 0.082 & ** & 0.137 & 0.187 & \\
\hline \multicolumn{13}{|l|}{ Interaction controls } \\
\hline Non-startup & -0.003 & 0.046 & & -0.129 & 0.089 & & -0.208 & 0.060 & ${ }^{* * *}$ & 0.660 & 0.119 & *** \\
\hline Partners & 0.040 & 0.018 & ** & -0.073 & 0.153 & & 0.129 & 0.077 & * & 0.404 & 0.173 & ** \\
\hline \multicolumn{13}{|l|}{ Primary goal interactions } \\
\hline davoid x non-scratch & 0.046 & 0.040 & & 0.311 & 0.305 & & -0.065 & 0.076 & & 0.201 & 0.117 & * \\
\hline davoid $x$ partners & -0.072 & 0.046 & & 0.412 & 0.174 & ** & 0.113 & 0.113 & & -0.202 & 0.214 & \\
\hline dwork x non-startup & 0.066 & 0.027 & ${ }^{* *}$ & -0.012 & 0.244 & & 0.202 & 0.086 & ** & -0.026 & 0.160 & \\
\hline dwork x partners & 0.006 & 0.040 & & 0.022 & 0.238 & & 0.098 & 0.068 & & 0.023 & 0.298 & \\
\hline dbuild $x$ non-startup & -0.025 & 0.029 & & -0.044 & 0.148 & & 0.129 & 0.067 & ${ }^{* *}$ & 0.026 & 0.160 & \\
\hline dbuild $x$ partners & -0.010 & 0.051 & & -0.320 & 0.124 & ** & 0.202 & 0.072 & ${ }^{* * *}$ & -0.312 & 0.278 & \\
\hline dother $x$ non-startup & 0.031 & 0.019 & & -0.405 & 0.163 & ** & 0.109 & 0.104 & & 0.316 & 0.262 & \\
\hline dother x partners & -0.017 & 0.050 & & -0.190 & 0.162 & & 0.218 & 0.202 & & -0.287 & 0.233 & \\
\hline $\begin{array}{l}\text { Wald linear restriction te } \\
\text { davoid }=\text { dwork }=\text { dbuild } \\
=\text { dother }=0[\times 2(4)]\end{array}$ & 32.16 & 0.000 & $* * *$ & 145.47 & 0.000 & *** & 241.18 & 0.000 & $* \star *$ & 6.73 & 0.151 & \\
\hline
\end{tabular}

${ }^{*}$ indicates significant at the .10 level; ** at the .05 level; and ${ }^{* * *}$ at the .01 level 